\title{
Function of Traditional Art "Karungut" in Character Building Education of Dayak People in Central Kalimantan
}

\author{
$1^{\text {st }}$ Holten Sion \\ Faculty of Teachers and Education \\ University of Palangka Raya \\ Palangka Raya, Indonesia \\ sion.holten@gmail.com
}

\author{
$2^{\text {nd }}$ Muhamad Affandi \\ Faculty of Teachers and Education \\ University of Palangka Raya \\ Palangka Raya, Indonesia \\ affandimuhamad.pls@gmail.com
}

\begin{abstract}
On this modern era, many people only concern about how to improve the cognitive and psychomotor as the results of their children's education process. They usually did many ways to increasing that aspect but sometimes they forget the affective (attitudes) of their children. The affective aspect, which also known as character building may be interpreted as a series of planned activities conducted by adults to learners; in a purpose the learners may have knowledge and understanding and be able to apply the life values such as goodness, truth and sincerity as their everyday's habits. As the other tribes, Dayak's people in Central Kalimantan also have ways and tools which are functioned in character building, one of which is through traditional art named "Karungut". Karungut is a kind of oral art sung with particular rhymes and accompanied with traditional instrument named "Kecapi". This research aims to describe and analyze the function of Karungut in character building of Dayak's people in Central Kalimantan. The approach used in this research is one to describe and analyze the utterances or opinions of group of people or community, therefore the approach used by the researcher is qualitative. While the kind of ethnographic approach was used considering the objects being described and analyzed is a culture or system of social groups, including mindset, habits, and ways of Dayak's living in Central Kalimantan. Research data were collected using interview and documentation towards source people including: Karungut artists, community leaders, and Dayak's customary leaders. According to the data, the results concluded are: (1) There were 4 (four) functions of Karungut in character education building of Dayak's people in Central Kalimantan, namely: (a) informative function, (b) affirmative function, (c) persuasive function, and (d) prohibition function.
\end{abstract}

Keywords-Character, Karungut, Dayak's People, Central Kalimantan

\section{INTRODUCTION}

The principle of education is actually to develop knowledge (cognitive), skills (psychomotor) and attitudes as well as positive values (affection) in order to develop the positive values or characters of students, so they can grow as intelligent, skillful and religious human beings. The statement is in line with the opinion of Hasanah (2013) and Marzuki (2012) that stated that "education is not merely about process and facilities supply which only focus on knowledge mastery, but it also facilitates the characters development". The abovementioned statement affirms that the final goal of education activity is to bear human beings who have positive values which are in line with the culture where they come from.

Characters are natural things of individual to react towards situation and condition which are based on morality values. Somebody's characters might be understood by his/her attitudes or behaviors in everyday life. This opinion is in line with the definition of character by Lickona (2012) who said "the charaters are manifestated into real actions of good, honest, responsible and respectful behaviors towards others". That definition of character goes together with Wynne (in Ersis, 2014) that stated "characters denote and focus on how to apply goodness values in real actions or everyday life". Therefore, it can be concluded that character education is a human activity of which there is an action to teach the next generation (Doni, 2017). In addition to that, the aim of character education is to develop individual sustainably and train self competence to be better. This opinion was agreed by Kurniawan (2014) who stated that "in principle, the values of character education are the development of Indonesian ideology".

The art of "Karungut" is an oral work which is sung with unique rhymes and accompanied by traditional instrument named "kecapi" (Setiawan 2016). The assumption about how the art connects to the character education can be found on Anna's writing (2015) that stated "to develop characters, the close element which is easy to receive is by cultural art". The statement elaborates that through arts activities, humans' characters can be completely developed human beings as individual, social person, and God's creation. The opinion is in line with Wardani's (2011) that said "to the next generation who acts as nation's asset for Indonesian human development, one thing needs to be concerned is the 
actualization of character education through cultural arts.

For Dayak people, the art of "Karungut" is not merely about singing its lyrics beautifully as an entertainment, but more than that Karungut consists of goodness values. The goodness values are: cooperation in harmony, ethics and morality, partnership, responsibility, honesty, justice, self confidence, etc. This goes together with Setiawan's (2016) that said "Karungut delivers the rhymes about goodness and wisdom about life concerning legend and warning of human's life and Dayak's life in specifically. The lyrics in "Karungut" is usually written with ending rhymes: $(a, a, a, a)$ or $(a, a, b, b)$ or $(a, b, a, b)$. This art of "Karungut" is usually performed on official events, such as : the commemoration of historical events, customary ceremony, wedding ceremony, time of planting/ harvesting paddy (harvesting event), welcoming guests, and on spare time as we usually sing on any song in general. This research aims to describe and analyze the function of Karungut in character education building of Dayak people of Central Kalimantan.

\section{METHODS}

The approach used in this research is qualitative, and as Bodgan and Taylor said (in Moleong, 2007) that qualitative methodology is a research procedure which results descriptive data in forms of both written words and oral statement from people and behaviors being observed. Viewed from its nature, this research can be categorized as ethnography research which means to elaborate and interpreted a culture or a system of social group, on which the researcher examined the group and observed the behaviors, habits, and their living patterns. Data collection were conducted by having: (a) interviews, (b) observation, and (c) documentation. Data analysis technique conducted by interactive analysis technique as determined by Milles and Huberman (1992) which consisted: reduction, presentation, verification, and conclusion.

\section{RESULTS AND ANALYSIS}

Results of this study found 4 (four) functions of "Karungut": (1) informative, (2) affirmative, (3) persuasive, and (4) prohibiting.

\section{A. Informative Function}

The informative function can be described as a learning activity about characters values of Dayak people in Central Kalimantan.This opinion was strenghtened by Siti Arnisyah's research result (2017) that concluded that "each verse and line of Karungut lyrics delivers a meaning for Dayak Ngaju people such as: a). teaching about life values, b) implementation form of Huma Betang philosophy, and c) respect for others. This opinion goes with Kanti's research (2007) that concluded Karungut as a media of public information was proved to be very important because it delivers morality messages, education, health and actual issue in local and national level. The results were in line with the interviews of Karungut artists that in general said "the lyrics were made on purpose so the goal of the lyrics created can be enjoyed by listeners, known and understood well". The statements of those artists were confirmed by Michael Risdianto's opinion (2016), who said that "Karungut has a character which is very communicative, because its messages delivered in form of verses in Dayak language and it is easy to understand". Following is a verse of Karungut taken as an example which showed the informative function.

$\begin{array}{ll}\text { Dayak Language } & \text { English } \\ \text { Title "Gunan Sakula" } & \text { Title "School Goal" } \\ \text { Katika Itah masih tabela } & \text { When we are still young } \\ \text { Keleh balajar ela } & \begin{array}{l}\text { Use the time for } \\ \text { hakalayan }\end{array} \\ \text { Gawi sakula tutu baguna } & \text { Since school is very } \\ \text { Akan pambelum andau } & \text { important } \\ \text { harian } & \text { For ourfuture life }\end{array}$

\section{B. Affirmative Function}

This function is important as a way to avoid something missed or misled from what have been known and understood by listeners about positive values (characters). The affirmative function of morality messages in terms of character education is not apart from repetition activity of messages have been delivered through "Karungut". This statement goes with Irwanto's opinion (1991) who observed the meaning of Decay Theory that said "memory becomes worn-out so the memory being scraped which causes it decreasing if things never be repeated (rehearsal)". According to the interviews with some artists of Karungut in general said that "this repetition conducted in hope that the messages we have delivered beforehand to listeners will be kept in mind, it means that messages will always be stored in listeners' mind". Following is a verse of Karungut taken as an example which showed the affirmative function.

$\begin{array}{ll}\text { Dayak Language } & \text { English } \\ \text { Title "Sinta Bangsa" } & \begin{array}{l}\text { Title "Nationalism" } \\ \text { Lulang-luli pansanan } \\ \text { Messages are delivered } \\ \text { inyampai }\end{array} \\ \text { Bara kota sampai akan } & \begin{array}{l}\text { From town to the village } \\ \text { desa }\end{array} \\ \text { Sama baju keang huang dried clothes on } \\ \text { sadai laundry } \\ \text { Katau itah mahaga } \\ \text { bangsa }\end{array}$

\section{Persuasive Function}

In the definition of persuade, beside the meaning as suggestion or order, there is also the word "generate", therefore the function of "Karungut" in this context acts as suggestion, order as well as motivation to someone to do something he or she wants to do. The statement was supported by some 
artists of "Karungut" from interviews done by reserchers who said that "we are the artists who are responsible to the messages we deliver and we affirm that, it is not only information or good news we convey, but we also invite and ask people for morality values may be implemented in practical life".

In "Karungut", there is also an effort to generate the motivation or passion of the listeners to be able to apply the message of art. It goes together with the definition of motivation as said by some experts, one of them is Sardiman (2006) who said "motivation is a trigger from inside to conduct activities in achieving goals". Following is a verse of Karungut taken as an example which showed the persuasive function.

\begin{tabular}{|c|c|}
\hline Dayak Language & English \\
\hline $\begin{array}{l}\text { Title "Mahaga Petak } \\
\text { Danum" }\end{array}$ & $\begin{array}{l}\text { Title "Taking Care } \\
\text { The Nation }\end{array}$ \\
\hline $\begin{array}{l}\text { Inyampai } k u \\
\text { gagenep biti }\end{array}$ & $\begin{array}{l}\text { I Tell This news to } \\
\text { everyone }\end{array}$ \\
\hline $\begin{array}{l}\text { Mangat itah ela landang } \\
\text { laya }\end{array}$ & For not being ignorant \\
\hline $\begin{array}{l}\text { Himbing lenge kilau } \\
\text { tampung kunci }\end{array}$ & $\begin{array}{l}\text { Be always aware and } \\
\text { alert }\end{array}$ \\
\hline $\begin{array}{l}\text { Haga petak danı } \\
\text { tuntang bahu himba }\end{array}$ & are the na \\
\hline
\end{tabular}

\section{Prohibition Function}

Prohibition or warning according to Kamus Besar Bahasa Indonesia has definition as order (rules) which prohibits an action, or something prohibited because it is considered sacred or holy: taboo, or something prohibited. According to the definition, acted as prohibition function, there are some behaviors follow the orders or rules which are not allowed to be done by anyone and anywhere. The behaviors meant here are the behaviors prohibited by rules and state laws and behaviors prohibited by rules and customary laws in Dayak people in Central Kalimantan. Empirically, this statement can be seen in the research results of Muriyat, Suwarno (2015) entitled "Budaya Dayak Ngaju dalam Karungut Sansana Bandar Huntip Batu Api, with one of his results "that karungut sansana Bandar Huntip Batu Api consists pedagogical values which teach Dayak people of (a) following their belief to divine substance, and (b) giving understanding, advice, suggestion in living life together with society. Based on the interview with some artists of "Karungut", it was gained the answers in general as follow " in this art lyrics, what is most important to deliver is a prohibition to people to not doing anything prohibited". Following is a verse of Karungut taken as an example which showed the prohibition function.

$\begin{array}{ll}\begin{array}{l}\text { Dayak Language } \\ \text { Title }\end{array} & \begin{array}{l}\text { English } \\ \text { Title "Stah Awakan } \\ \text { Narkoba" }\end{array} \\ \text { From Drugs" } \\ \text { This story is made and } \\ \text { Hapa nangaja } & \begin{array}{l}\text { Told } \\ \text { To prohibit the young } \\ \text { generation }\end{array}\end{array}$

$\begin{array}{lll}\text { tabela } & \begin{array}{l}\text { Do not ever involve in } \\ \text { drugs } \\ \text { Ela umba kuman } \\ \text { narkoba } \\ \text { bringing you to the jail }\end{array} \\ \begin{array}{l}\text { Jete jamban manuju } \\ \text { panjara }\end{array} & \end{array}$

\section{CONCLUSION}

According to the research results gained from interviews, observation, and documentaion study, it can be concluded that:

There are 4 (four) functions of the art of "Karungut", namely: (1) the function to inform the characters values to people or listeners, (2) the function to affirm or warn the character values to be remembered by listeners, (3) the function to persuade (motivation) with the goal to invite and support people or listeners to do character values, and (4) the function of prohibition in order that people avoid breaking the character values such as written in the lyrics and verses of "Karungut".

\section{SUGGESTIONS}

There are some suggestions provided from the research results as follow: (1) To all parties, especially local government is expected to be able to arrange as well as to apply development and preservation system toward this art, it is essential for the art can last in this global and millenium era, (2) To local government, in this context is the Office of Education and Culture is expected to arrange a system of effective character education implementation, one of them is by conducting the optimalization of Karungut function itself.

\section{ACKNOWLEDGEMENTS}

The writers would like to extend their gratitudes to the Dean of Faculty of Teachers and Education, University of Palangka Raya by the time this journal can be published and presented on International Conference on Teachers Traiing and Education (ICTTE) in UNS Solo.

\section{REFERENCES}

[1] Agus Maladi Irianto. Kesenian Tradisional Sebagai Sarana Strategi Kebudayaan di Tengah Determinasi Teknologi Komunikasi. NUSA, Vol. 12. No. 1 Februari 2017. Semarang (2017).

[2] Andjar, Any, Menyingkap Serat Wedatama. Aneka Ilmu. Semarang (1983).

[3] Anna, dkk. Pembentukan Karakter Berbasis Pendidikan Seni Budaya Tingkat Sekolah Dasar di Kota Malang Jawa Timur. Laboratorium Antropologi untuk Riset dan Aksi (LAURA) Antropologi UGM bekerja sama dengan Balai Pelestarian Nilai Budaya, Yogyakarta (2015).

[4] Budhisantoso, S, Kesenian dan Kebudayaan di Indonesia, makalah dalam diskusi. Terbitan buku perdana STSI PRESS. Surakarta (1991). 
[5] Cut Zurnali. Pengaruh Pelatihan dan Motivasi Terhadap Perilaku Produktif Karyawan Divisi Long Distance PT Telkom Tbk, Tesis, Unpad, Bandung (2004).

[6] Darsono, Max. dkk. 2000. Belajar dan Pembelajaran. IKIP Semarang Press, Semarang (2000).

[7] Davies, Ivor K. (penerjemah: Sudarsono S., dkk.) Pengelolaan belajar. Jakarta: C.V. Rajawali dan PAU-UT. Jakarta (1987).

[8] Dimyati. Belajar dan Pembelajaran. Depdikbud. Jakarta (2005).

[9] Djamarah,Syaiful Bahri. Strategi Belajar Mengajar.Rineka Cipta. Jakarta (2002).

[10] Doni Kusuma A. Pendidikan Karakter. Grasindo. Jakarta (2007).

[11] Ersis , W.A. Pendidikan Karakter. Niaga Sarana Mandiri. Bandung (2014)

[12] Gredler, Margaret E. Bell. (penerjamah Munandir). Belajar dan Membelajarkan. C.V. Rajawali dan PAU-UT. Jakarta (1991).

[13] Hamalik,Oemar. Proses Belajar Mengajar. Bumi Aksara. Bandung (2003).

[14] Hasanah. Implementasi Nilai-nilai Karakter Inti di Perguruan Tinggi. Jurnal Pendidikan Karakter Tahun III, Nomor 2, Juni 2013 UNY. Yogyakarta (2013)

[15] Hastanto, Sri. "Ilmu dan Seni" dalam Seminar Peksiminas I 2-5 Oktober 1991, STSI PRESS. Surakarta (1991).

[16] Hastanto, Sri. “ Pendidikan Karawitan: Situasi dan AnganAngan”, dalam jurnal seni STSI Surakarta edisi Maret 1997. Surakarta (1997)

[17] https://www.scribd.com/doc/68184633/Pengertian-LupaDan-Teori-Lupa (diambil 7 Mei 2018).

[18] http://www.artikelsiana.com/2017/08/pilar-pilar-pendidikankarakter-definisi-pengertian.html (diambil 11 April 2018)

[19] http://www.rumpunnektar.com/2013/01/penyesuaiandiksi.html (diambil 18 April 2018).

[20] http://karya-

ilmiah.um.ac.id/index.php/disertasi/article/view/44899 (diambil 11 April 2018).

[21] http://karakterbangkit.blogspot.com/2009/12/pendidikanberbasis-karakter.html (diambil 11 April 2018).

[22] http://www.artikelmateri.com/2015/12/seni-adalahpengertian-fungsi-jenis-macam-contoh.html (diambil 7 April 2018).

[23] http://www.artikelsiana.com/2015/09/pengertian-seni-fungsimacam-macam-seni.html (diambil 7 Mei 2018)

[24] https://familinia.com/pengertian-seni-beserta-fungsi-danmacam-macam-seni/ (diambil 7 Mei 2018).

[25] Irianto. Psikologi Umum. Gramedia Pustaka Utama. Jakarta (1991).

[26] Kamiran. Pembelajaran Karawitan Di Sekolah Dalam Rangka Pendidikan Karakter Bangsa. Tesis tidak dipublikasi. Universitas Muhammadiyah Malang: Malang (2012).

[27] Kanti, W. Pesan-pesan Karungut Sebagai Media Informasi Publik di Palangka Raya. http://kantiwalujo.blogspot.co.id/2008/12/pesan-pesankarungut-sebagai-media.html (diambil 10 April 2018) Puslibang APTEL SKDI. Badan Litbang SDM-Depkominfo. Jakarta (2008).

[28] Kristiandi. Makna dan Fungsi Kesenian Rakyat "Reog Tradisi" dalam Konteks Ritual Upacara Adat Mondosiyo di
Tawangmangu, Kabupaten Karanganyar. Karanganyar (2006).

[29] Kurniawan, Anton. Survey Tentang Pendidikan Karakter Melalui Mata Pelajaran Seni Budaya Tingkat SMP Negeri di wilayah Kecamatan Wonosari. Skripsi. UNY, Yogyakarta (2014).

[30] Lichona. Educating for Teacher. Penerjemah Juma Abdu Wawaungo. Remaja Rosdakarya. Bandung (2012).

[31] Marzuki Bangsaki. Pengembangan Soft skill Berbasis Karakter Melalui Pembelajaran IPS Sekolah Dasar. Disampaikan dalam Seminar Nasional di Madiun 1 April 2012 (2012).

[32] Mulyasa. Manajemen Pendidikan Karakter. Bumi Angsara. Jakarta (2011).

[33] Muriyat, Suwarno. Budaya Dayak Ngaju dalam Karungut Sansana Bandar Huntip Batu Api. (Disertasi, Program Studi Pendidikan Bahasa Indonesia, Pascasarjana, Universitas Negeri Malang). Malang (2015).

[34] Michel R. Karungut Dayak Ngaju: Dengan Tergesa Sang Anak Burung Tiung Itupun Bergegas Kembali Pulang ke Kampung Halaman di Malang Selatan http://michaelrisdianto.blogspot.co.id/2016/03/karungutdayak-ngaju-dengan-tergesa.html (diambil 11 April 2018). Malang (2017).

[35] Miles, Matthew B., dan A. Michael Huberman. Analisis Data Kualitatif. Universitas Indonesia-UI Press. Jakarta (1992).

[36] Moleong, Lexy J. 2007. Metodologi Penelitian Kualitatif: Remaja Rosdakarya. Bandung (2007)

[37] Moleong, Lexy J., 1994. Metodologi Penelitian Kualitatif. Bandung: Remaja Rosdakarya. Bandung (1994).

[38] Pusat Kurikulum Departemen Pendidikan Nasional. Bahan Pelatihan Penguatan Metodologi Pembelajaran Berdasarkan Nilai-nilai Budaya untuk Membentuk Daya Saing dan Karakter Bangsa. Depdikbud. Jakarta (2010).

[39] Rosidi, Ajip. Satra dan Budaya.Pustaka Jaya. Jakarta (1995).

[40] Sardiman,A.M. Interaksi dan Motivasi Belajar Mengajar. Grafindo. Jakarta (2006).

[41] Semiawan, Conny.. Pendidikan Seni dalam Pendidikan Nasional, APSI. Bandung (2006).

[42] Setiawan Agus. Kesenian Karungut Suku Dayak Kalimantan Tengah. https://nusantaranews.co/kesenian-karungut-sukudayak-kalimantan-tengah/ (diambil: 10 April 2018). Kalteng Post. Palangka Raya (2016)

[43] Siti, Arnisyah. Nilai Pendidikan Karakter Dalam Syair Karungut Dayak Ngaju Kalimantan Tengah dan Relevansinya dengan Pembelajaran Bahasa Indonesia di SMAN 1 Katingan Hulu. Tesis tidak dipublikasi. Universitas Sebelas Maret: Solo (2017).

[44] Soedarso SP. Tinjauan Seni, Sebuah Pengantar Apresiasi Seni. Saku Dayar Sana. Yogakarta (1990).

[45] Strauss, Anselm dan Juliet Corbin. Dasar-dasar Penelitian Kualitatif. Pustaka Pelajar. Yogjakarta (2003).

[46] Suanda, Endo. Kesenian dan Pluralitas Kultur. APSI Bandung (2006).

[47] Suparlan. Pendidikan Karakter. https://suparlan.org/2/pendidikan-karakter (diambil 11 April 2018). Jakarta (2012).

[48] Wardani, Cut Kamaril. Pendidikan Seni Berbasis Budaya Dalam Meningkatkan Multikecerdasan. APSI. Bandung (2006).

[49] Wibowo, A. Pendidikan Karakter, Srategi Membangun Karakter Bangsa Berperadaban. Pusaka. Yogyakarta (2012). 